\title{
Pathogenesis of mixed infection by Spironucleus sp. and Citrobacter freundii in freshwater angelfish Pterophyllum scalare
}

\author{
Sílvia U. Gallani a , Fernanda de A. Sebastião a , Gustavo M.R. Valladão a , André Z. Boaratti ${ }^{\text {b }}$, \\ Fabiana Pilarski a, * \\ a Laboratory of Pathology of Aquatic Organisms, Aquaculture Center (CAUNESP), Universidade Estadual Paulista (UNESP), Jaboticabal, São Paulo, 14870, \\ Brazil \\ ${ }^{\mathrm{b}}$ Laboratory of Ornamental Fish, Aquaculture Center (CAUNESP), Universidade Estadual Paulista (UNESP), Jaboticabal, São Paulo, 14870, Brazil
}

\section{A R T I C L E I N F O}

\section{Article history:}

Received 5 July 2016

Received in revised form

25 August 2016

Accepted 2 September 2016

Available online 4 September 2016

\section{Keywords:}

Aquaculture

Aquarium

Bacteria

Disease

Ornamental

Parasite

\begin{abstract}
A B S T R A C T
The present study was carried out to identify and describe the pathology of the freshwater angelfish Pterophyllum scalare during chronic mortality in an in-door aquaculture system. Scraping of the integument and gills and the collection of intestinal contents to search for external and internal parasites were performed. Kidneys were collected aseptically for the microbiological analysis and the isolates were subjected to antibiotics to test for susceptibility. Subsequently, necropsy for macroscopic assessment and collection of internal organs for histopathology were performed. The fish exhibited lethargy, lip tumor, hemorrhage and liver granuloma. No ectoparasites were diagnosed. Endoparasites of the genus Spironucleus were found in large numbers in the intestine of the affected fish. In the microbiological analysis, Citrobacter freundii was isolated from the kidney and identified by colony PCR. This bacterium showed susceptibility to three of the eight antibiotics evaluated: ciprofloxacin, cefoxitin and tetracycline. For the pathological analysis, liver and spleen granulomas were present. In the intestinal tissue, a large and unusual amount of mast cells and their free granules were described and discussed in detail. The present study showed that mast cells play an important role during the chronic infection of freshwater angelfish.
\end{abstract}

() 2016 Elsevier Ltd. All rights reserved.

\section{Introduction}

The ornamental fish hobby is among the most popular industries worldwide, creating multi-million dollar industries. The freshwater angelfish Pterophyllum scalare is a South American cichlid from Amazonia that is commonly traded in the global ornamental market [1]. The freshwater angelfish and several other native species are commonly farmed in other countries due to their easy reproduction and as a consequence, the export and import become important factors to consider because of the susceptibility of the fish to different pathogens.

Diplomonads from the genus Spironucleus (Hexamita) are flagellate protozoa endoparasites that inhabit the fish gastrointestinal tract, but affect the animal systemically by penetrating the intestinal mucosa to reach the blood stream and consequently other

\footnotetext{
* Corresponding author. Rod. Paulo Donato Castellane, s/n, CEP: 14884-900, Jaboticabal, São Paulo, Brazil.

E-mail address: fabianap@caunesp.unesp.br (F. Pilarski).
}

organs. This parasite was diagnosed to cause lip tumors in fish [2] and granulomas in the liver and spleen [3]. Infestations of flagellates are among the predominant intestinal diseases in cichlids [4,5], fish for consumption [5] and ornamentals [6]. Freshwater angelfish and the discus Symphysodon discus are the ornamental species most affected by this disease $[4,7,8]$. The pathology and the association of this genus with secondary pathogens such as bacteria, however, have not been described.

Both the aquatic environment and the intestinal tract of fish are inhabited by a wide range of bacteria [9], which may affect the animals under stressful conditions. Aeromonas, Pseudomonas and Vibrio are the genera of bacteria notably responsible for causing disease outbreaks. Recent studies, however, have described significant infections by Citrobacter freundii in tilapia [10], carps [11,12] and eels [13], which are economically important fish for aquaculture. The infection caused by $C$. freundii results in inflammation and necrotic changes of internal organs, exophthalmia and bleeding in the eyes [14]. C. freundii was recently described in freshwater angelfish [15], however, little is known about this infection compared 
to the other bacteria mentioned.

The infections by both of the pathogens discussed in the present study begin inside the gastrointestinal tract. Various studies have noted the importance of innate and adaptive immune cells and their relationship with microorganisms in the gastrointestinal tract of fish [16-18]. More specifically, researches have described the role of mast cells (MC) for different intestinal infections in fish [19]. The present study described in detail the role of MC during chronic infection in a cichlid fish.

In the present study, parasitic and bacterial analyses for the diagnosis of chronic mortality in freshwater angelfish were carried out. For the $C$. freundii, the pathology was described and the susceptibility to antibiotics was evaluated.

\section{Materials and methods}

\subsection{Fish and necropsy description}

Freshwater angelfish were reared in an in-door system. The fish that exhibited chronic mortality (1-3 dead fish per day) were analysed. The fish were kept in $450 \mathrm{~L}$ tanks at a density of 120 fish per tank. Water quality parameters were maintained constant for the dissolved oxygen (5.5-6.5 mg/L), $\mathrm{pH}(6.0-6.5)$ and temperature $\left(25-27^{\circ} \mathrm{C}\right)$.

All of the necropsied fish $(n=13)$ were anaesthetized with benzocaine at $0.1 \mathrm{~g} / \mathrm{L}\left(\right.$ E1501 Sigma $\left.{ }^{\circledR}\right)$ and euthanized by severing of the spinal cord for necropsy. All fish presented lethargy, lip tumors, exophthalmia and hemorrhages in the integument (Fig. 1a,b). The fish showed granulomas in the liver and the spleen during the necropsy.

The study followed the Ethical Principles in Animal Research adopted by the National Council for the Control of Animal Experimentation and was approved by the Ethics and Animal Welfare Committee of Universidade Estadual Paulista - UNESP (protocol number 8.102/16).

\subsection{Parasitological analysis}

The integument and the gills $(\mathrm{n}=11)$ were scraped using glass slides before the fish were anaesthetized. The material was assessed using a Nikon microscope $E 200^{\circledR}$ to search for ectoparasites.

To search for endoparasites, fish were necropsied after euthanasia and the contents of the stomach and the intestine were placed on a glass slide. The tissue was scraped using a cover slip and assessed under a light microscope. Slides were stained with May Grünwald-Giemsa-Wright (MGGW) for $10 \mathrm{~min}$ to describe the flagella of the parasites.

\subsection{Bacterial analysis}

The kidney and spleen $(\mathrm{n}=2)$ were collected aseptically, inoculated in TSB broth (Tryptic Soy Broth, himedia ${ }^{\circledR}$, India) and incubated at $30{ }^{\circ} \mathrm{C}$ for $24 \mathrm{~h}$. The samples were then plated on TSA (Tryptic Soy Agar, himedia ${ }^{\circledR}$, India) at the same temperature and incubation time for gram staining and purity assessment. To identify the isolates, colony PCR was carried out by sequencing the 16S rRNA gene using the primers 8F (5'-AGAGTTTGATYMTGGCTCAG-3') and 907R (5'-CCGTCAATTCMTTTRAGTTT- $3^{\prime}$ ). The PCR conditions were performed as described by Sebastião et al. [20]. The 16S rRNA sequence was identified using the Basic Local Alignment Search Tool (BLAST) from the National Center for Biotechnology Information (NCBI).

The antimicrobial susceptibility of $C$. freundii was evaluated using a diffusion method in MHA (Mueller Hinton Agar, himedia ${ }^{\circledR}$, India) according to Clinical and Laboratory Standards Institute [21]. Briefly, a suspension of each isolate was adjusted to $0.5 \mathrm{McFarland}$ standard turbidity. Using a sterile swab, the suspension was inoculated in MHA agar in duplicate. The antibiotic disks were placed on each plate and were incubated at $28{ }^{\circ} \mathrm{C}$ for $24 \mathrm{~h}$. The isolates were classified as resistant or susceptible to each antibiotic depending on the diameter of the inhibition halo, as described for aquatic bacteria [22].

The antibiotic discs used in the study were florfenicol $(30 \mu \mathrm{g}$, Oxoid $^{\circledR}$, USA), oxytetracyclin $\left(30 \mu \mathrm{g}\right.$, Oxoid $^{\circledR}$, USA $)$, ampicilin $(10 \mu \mathrm{g}$, Laborclin $^{\circledR}$, Brazil), enrofloxacin (5 $\mu \mathrm{g}$, Sensifar ${ }^{\circledR}$, Brazil), tetracycline $\left(30 \mu \mathrm{g}\right.$, Sensifar ${ }^{\circledR}$, Brazil), ciprofloxacin (5 $\mu \mathrm{g}$, Laborclin ${ }^{\circledR}$, Brazil), cefoxitin $\left(30 \mu \mathrm{g}\right.$, Laborclin ${ }^{\circledR}$, Brazil) and cefalotin $(30 \mu \mathrm{g}$, Laborclin $^{\circledR}$, Brazil).

\subsection{Histopathology}

The kidneys, spleen, liver and intestine from five freshwater angelfish were sampled and fixed in buffered formaldehyde (10\%) for the histopathological analyses. Tissue samples were dehydrated in grades of ethanol, cleared in xylene, embedded in paraffin, sectioned at $5 \mu \mathrm{m}$ and stained with haematoxylin-eosin (HE). Photomicrographs were prepared using the microscope Nikon E200 ${ }^{\circledR}$ equipped with a Moticam $2300^{\circledR}$ system.

\section{Results}

\subsection{Parasitological analysis}

No ectoparasites were found in the tegument and the gills. No endoparasites were found in the stomach. The intestinal analysis, however, showed high levels of infection by a microscopic
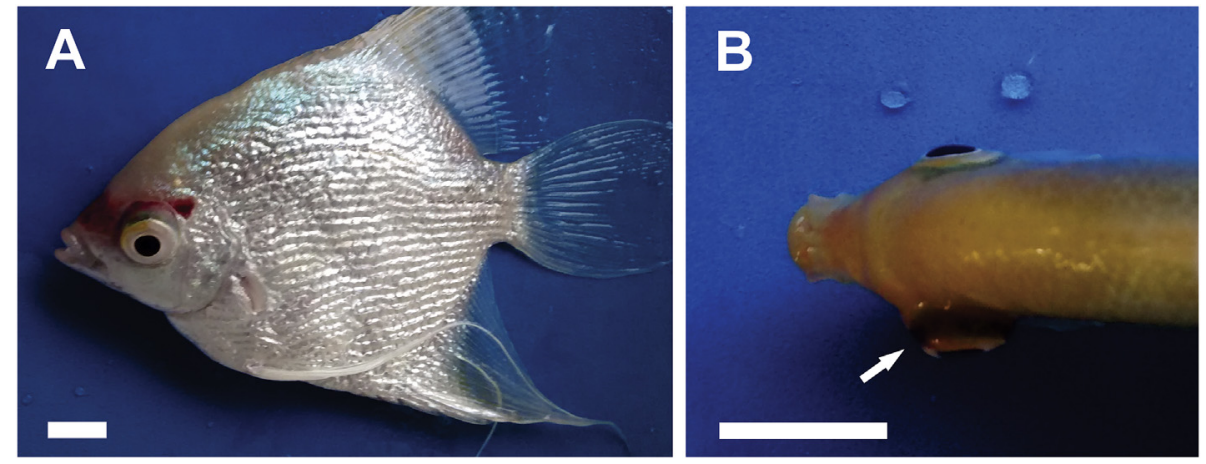

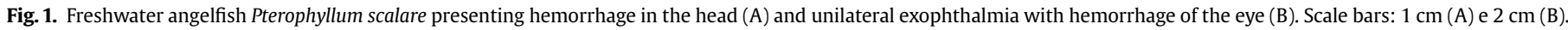


protozoan with a prevalence of $100 \%$.

The parasites were highly motile, rotating around their own axis (Supplementary video 1 ). In general, the pyriform shape was noted to have $11.76 \pm 0.96 \mu \mathrm{m}$ in length and $4.32 \pm 0.54 \mu \mathrm{m}$ in width. Six anterior flagella and two additional posterior flagella were observed in the MGGW slides. Based on these characteristics, the parasite was identified as a Spironucleus species.

Supplementary video related to this article can be found at http://dx.doi.org/10.1016/j.micpath.2016.09.002.

\subsection{Bacterial analysis}

Two bacteria (LP15/1 and LP15/3) were isolated from two fish, of which the microbiological analysis revealed rough and opaque colonies (Fig. 2a) formed by gram-negative short rods (Fig. 2b). Both individual colonies were identified as $C$. freundii via colony PCR using the ribosomal 16S gene and direct DNA sequencing, assuming a $100 \%$ coverage and identity similar to or higher than $98 \%$ of the reference species in GenBank.

The $C$. freundii isolates presented the same pattern of susceptibility to antibiotics (Table 1). The isolates were susceptible only to ciprofloxacin, cefoxitin and tetracycline. Both isolates were likewise resistant to five out of eight antibiotics tested, including florfenicol and oxytetracycline, which are commonly used in aquaculture.

\subsection{Histopathology}

Histological sections of the liver revealed moderate lipid degeneration (Fig. 3A) and granulomas (Fig. 3B). In the splenic tissue, spherical granulomas (Fig. 3C) were present with a darker core (composed of dead cell material) and surrounded by numerous macrophages (Fig. 3D).

In the intestine, numerous Spironucleus and intestinal bacteria were observed in the lumen (Fig. 4A). A large amount of MC was observed in the lamina propria (Fig. 4B). The MC were also observed transitioning to the basement membrane (epithelium). This cell was eosinophilic when stained with HE. The granules of the MC ranged in size. Furthermore, free extracellular granules of MC were observed (Fig. 4C).

\section{Discussion}

The freshwater angelfish is one of the most traded species of ornamental fish, however, there is a lack of scientific descriptions of the diseases that affect these animals. Previous studies describe parasitic infestations caused by Spironucleus vortens [2,4], Ichthyophthirius multifiliis, unidentified trichodinids, Dactylogyrus spp., Gyrodactylus spp. [23], unidentified Monogenea species [24], Capillaria spp [25]. and Tetrahymena [26], in addition to bacterial infections caused by Mycobacterium spp [27,28]. and A. hydrophila [29].

Hemorrhaging in the eye and exophthalmia were observed in the present study. Similar clinical signs were observed for cyprinids infected with $C$. freundii [14]. These changes are normally associated to bacterial infection, however, Spironucleus affects the fish head and causes lip tumors and bleeding [30], which can extend up to the eyes due to the structures being within close approximation morphologically for this fish species [31]. described granulomatous liver, numerous melano-macrophage centers in the spleen and inflammation of the intestine in fish infected by S. vortens. Granulomas [32], inflammatory and necrotic changes in the internal organs [14] were also described in fish infected by $C$. freundii. Both C. freundii and Spironucleus sp. present similar histopathological alterations in fish, but a unique indicator of spironucleosis is the presence of a lip tumor, which was observed in this study and several other descriptions.

Granulomatous diseases in aquaculture are usually reported in cases of Mycobacterium [33] and Francisella [34] infections. The histopathology results of the present study, however, indicated that the mixed infection by Spironucleus sp. and C. freundii culminated in diffused granulomas of the liver and spleen tissue in freshwater angelfish. A significant and unusual increase in the number of MC was observed in the intestine of infected freshwater angelfish. The involvement of $\mathrm{MC}$ in pathogenesis and protective immunity has been shown in some intestinal infections in mammals [35] and fish [19]. The presence of free granules indicates an immune response of MC in infections. Several authors reported that MC, eosinophils and neutrophils have an active form of cell death called extracellular DNA trap (ETosis) that releases free granules [35-39]. ETosis is a way for these cells to maintain their immunological and inflammatory effects, since the MC granules are provided with lysosomal enzymes, biogenic amines, proteoglycans and proteases [40].

Bacterial multi-resistance is one of the growing concerns in fish farming worldwide. The present study found $62.5 \%$ antimicrobial resistance of $C$. freundii. Similar bacterial multi-resistance was previously reported in ornamental fish $[41,42]$. Both $C$. freundii isolates showed susceptibility to ciprofloxacin, cefoxitin and tetracycline, which could be the preferred drugs for treatment. As discussed by Awad [43] and Abd-El-Ghany et al. [7], ciprofloxacin has demonstrated an efficacy worldwide to control or treat bacterial infections in fish. Pádua et al. [44] reported a similar result in which $C$. freundii strains isolated from farmed catfish Pseudoplatystoma reticulatum were sensitive to ciprofloxacin and tetracycline. Strains of $C$. freundii isolated from ornamental fish from Colombia,
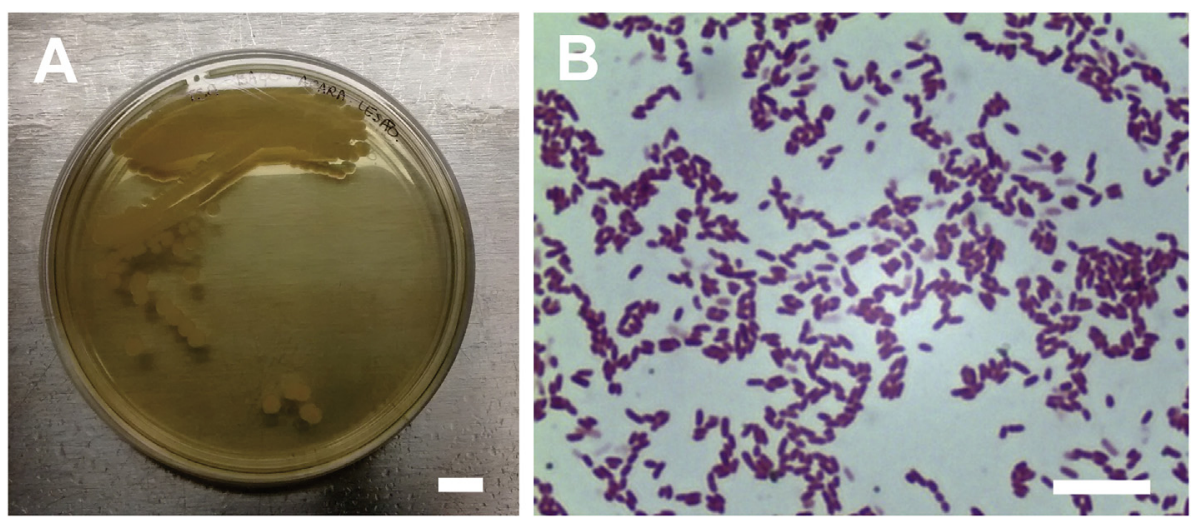

Fig. 2. Rough and opaque colonies (A) formed by gram negative bacteria (B). Scale bars: $1 \mathrm{~cm}(\mathrm{~A})$ e $100 \mu \mathrm{m}$ (B). 
Table 1

Antimicrobial susceptibility test for Citrobacter freundii strains.

\begin{tabular}{|c|c|c|c|c|}
\hline \multirow[t]{2}{*}{ Antibiotics } & \multicolumn{3}{|c|}{ Halo diameter (mm) } & \multirow[t]{2}{*}{ Susceptibility testing } \\
\hline & Stain 1 LP15/1 & Strain 2 LP15/3 & Standard-strain (sensitive) & \\
\hline Florfenicol & 16 & 15.5 & $\geq 37$ & $\mathrm{R}$ \\
\hline Oxytetracycline & 24 & 24 & $\geq 31$ & $\mathrm{R}$ \\
\hline Enrofloxacin & 24 & 23 & $\geq 40$ & $\mathrm{R}$ \\
\hline Tetracycline & 23 & 24.5 & $\geq 15$ & $\mathrm{~S}$ \\
\hline Ciprofloxacin & 29.5 & 29 & $\geq 21$ & $\mathrm{~S}$ \\
\hline Cefoxitin & 27 & 26 & $\geq 18$ & $\mathrm{~S}$ \\
\hline Cefalotin & 16 & 17 & $\geq 18$ & $\mathrm{R}$ \\
\hline Ampicillin & 20.5 & 20 & $\geq 36$ & $\mathrm{R}$ \\
\hline
\end{tabular}

R: resistant, S: susceptible.
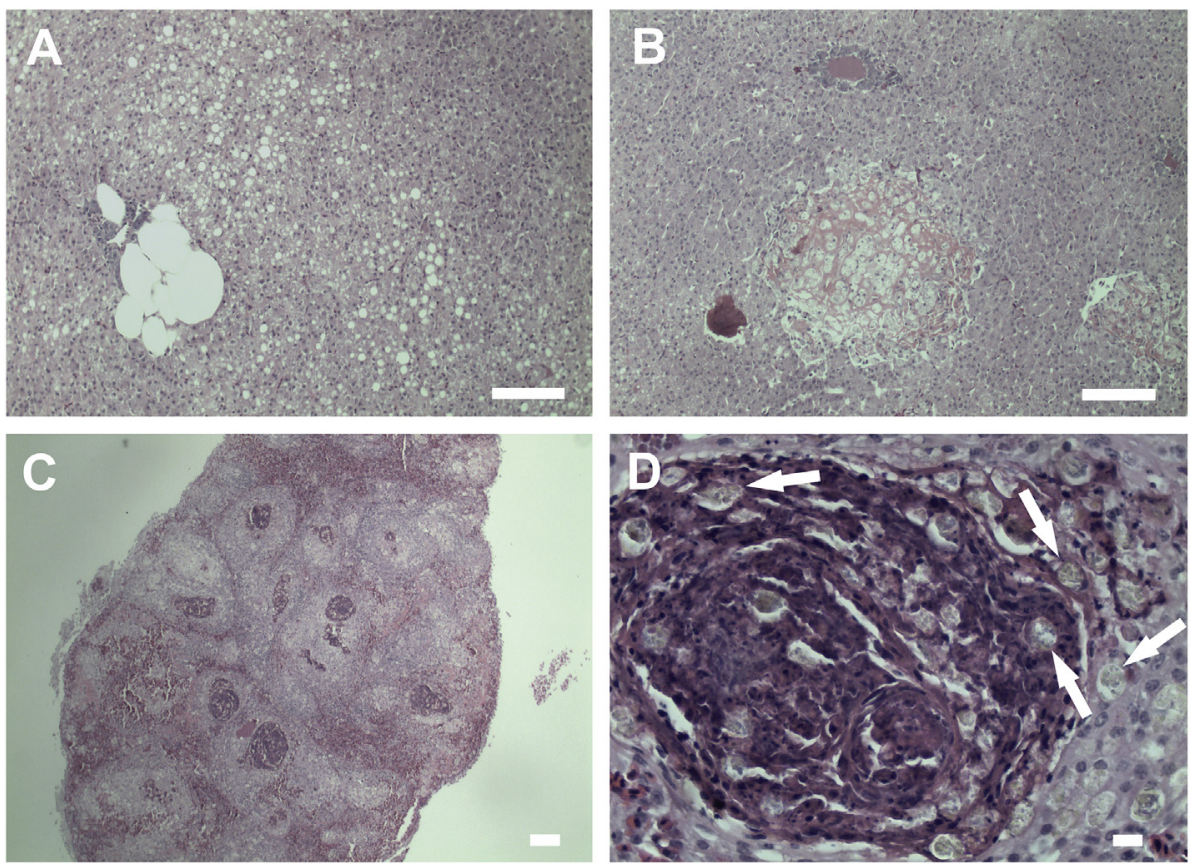

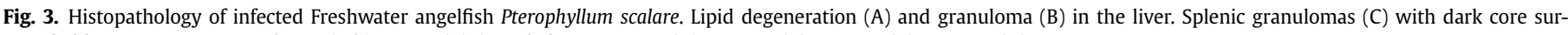
rounded by numerous macrophages (white arrow) (D). Scale bars: $100 \mu \mathrm{m}$ (A), $100 \mu \mathrm{m}$ (B), $100 \mu \mathrm{m}$ (C) e $10 \mu \mathrm{m}$ (D).
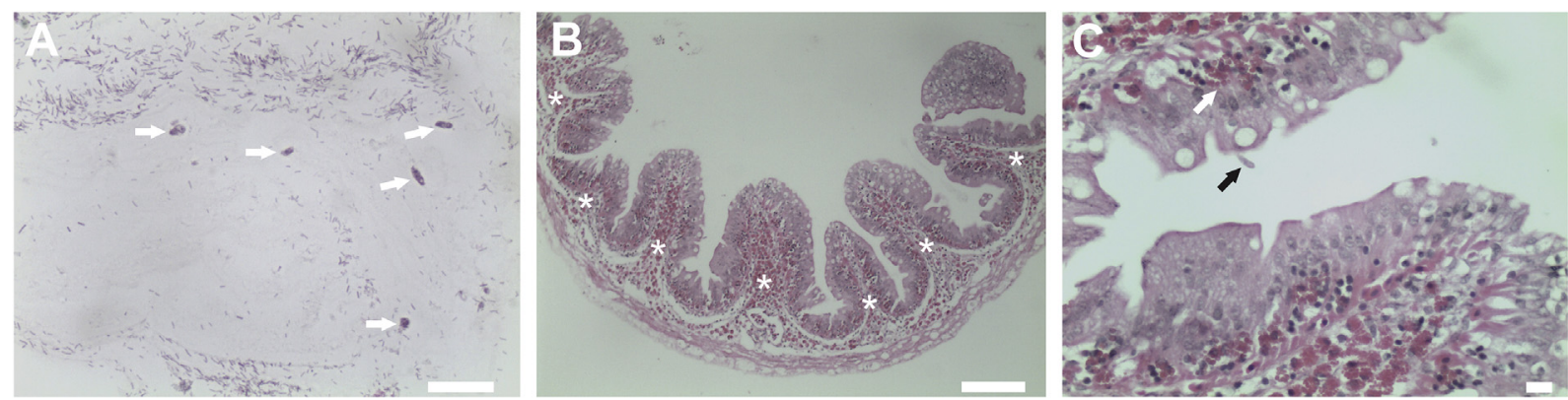

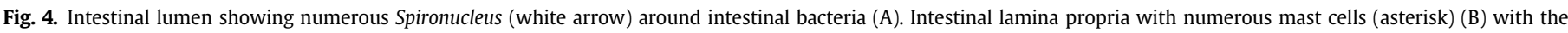
presence of free granules (white arrow) in the basement membrane attached near a parasite (black arrow) (C). Scale bars: $100 \mu \mathrm{m}(\mathrm{A}), 100 \mu \mathrm{m}(\mathrm{B}), 10 \mu \mathrm{m}(\mathrm{C})$.

Florida and Singapore, however, were resistant to these antibiotics [42]. Differences in the susceptibility of the same species of bacteria can be justified by the different origins of the strains (environmental change, fish species and previous exposure to antibiotics).

Treatments of parasites are also needed, as parasitosis is shown to be a gateway to the bacteria infection. Dimetridazole, metronidazole, mebendazole [45], garlic and its derivatives [46,47], and other herbs [8] are key molecules with potential to treat spironucleosis. In light of these considerations, the treatment should be performed carefully because the freshwater angelfish is often affected by an anomaly called swim bladder non-inflation during and after treatments $[48,49]$.

The present study reveals diagnostic and pathological descriptions of chronic mortality of freshwater angelfish caused by 
the mixed infection of $S$. vortens and $C$. freundii. Furthermore, the antibiotics ciprofloxacin, cefoxitin and tetracycline showed potential for future in vivo treatment protocols.

\section{References}

[1] M. Tavares-Dias, J.R.G. Lemos, M.L. Martins, G.T. Jerônimo, Metazoan and protozoan parasites of freshwater ornamental fish from Brazil, in: M. TavaresDias (Ed.), Manejo e sanidade de peixes em cultivo, Embrapa Amapá, Macapá, 2009, pp. 469-494.

[2] S.L. Poynton, W. Fraser, R. Francis-Floyd, P. Rutledge, P. Reed, T.A. Nerad Spironucleus vortens n. sp. from the freshwater angelfish Pterophyllum scalare: morphology and culture, J. Eukaryot. Microbiol. 42 (1995) 731-742.

[3] C.F. Williams, D. Lloyd, S.L. Poynton, A. Jorgensen, C.O. Millet, J. Cable, Spironucleus species: economically-important fish pathogens and enigmatic single-celled eukaryotes, J. Aquac. Res. Dev. (2011), http://dx.doi.org/10.4172/ 2155-9546.S2-002.

[4] G.C. Paull, R.A. Matthews, Spironucleus vortens, a possible cause of hole-in-thehead disease in cichlids, Dis. Aquat. Organ. 45 (2001) 197-202.

[5] K. Supamattaya, W. Phromkunthong, N. Suanyuk, H. Soliman, M. El-Matbouli, Spironucleosis in cultured red tilapia, Vet. Rec. (2012) 1-3. English Edition.

[6] C.F. Williams, A.R. Vacca, D. Lloyd, B. Schelkle, J. Cable, Non-invasive investigation of Spironucleus vortens transmission in freshwater angelfish Pterophyllum scalare, Dis. Aquat. Organ. 105 (2013) 211-223.

[7] N.A. Abd-El-Ghany, N.R. El-Khatib, S.S.A. Salama, Causes of mortality in Discus fish (Symphysodon) and trials for treatment, Egy. J. Aquac. 4 (2014) 1-12.

[8] K. Puk, L. Guz, Effects of medical plant extracts on the growth of the fish parasite Spironucleus vortens, Med. Weter. 70 (2014) 165-168.

[9] S.K. Nayak, Role of gastrointestinal microbiota in fish, Aquac. Res. 41 (2010) 1553-1573.

[10] S. Thanigaivel, S. Vijayakumar, S. Gopinath, A. Mukherjee, N. Chandrasekaran, J. Thomas, In vivo and in vitro antimicrobial activity of Azadirachta indica (Lin) against Citrobacter freundii isolated from naturally infected Tilapia (Oreochromis mossambicus), Aquaculture 437 (2015) 252-255.

[11] A. Lü, X. Hu, L. Zheng, A. Zhu, C. Cao, J. Jiang, Isolation and characterization of Citrobacter spp. from the intestine of grass carp Ctenopharyngodon idellus, Aquaculture 313 (2011) 156-160.

[12] W. Li, W. Yong, Identification and phylogenetic analysis of bacterium Citrobacter freundii from crucian carp Carassius auratus by 165 rDNA genes, J. Fish. Sci. 8 (2012) 10.

[13] F.Y. Yang, R.Z. Guan, Z.Q. Li, H.Z. Yu, Q.Y. Li, Identification of pathogenic Citrobacter freundii isolated from Anguilla marmorata, J. Jimei Univ. (Nat. Sci.) 2 (2013) 02.

[14] S. Jeremić, D. Jakić-Dimić, L.J. Veljović, Citrobacter freundii as a cause of disease in fish, Acta Vet. 53 (2003) 399-410.

[15] Ç. Ürkü, R.E. Yardımcı, Melek baliklarinda (Pterophyllum scalare) Capilaria sp. enfestasyonu ve bakteriyel septisemi, J. Fish. Sci. 7 (2013) 232-240.

[16] D. Gomez, J.O. Sunyer, I. Salinas, The mucosal immune system of fish: the evolution of tolerating commensals while fighting pathogens, Fish. Shellfish Immun. 35 (2013) 1729-1739.

[17] C.C. Lazado, C.M.A. Caipang, Mucosal immunity and probiotics in fish, Fish. Shellfish Immun. 39 (2014) 78-89.

[18] J.H. Rombout, G. Yang, V. Kiron, Adaptive immune responses at mucosal surfaces of teleost fish, Fish. Shellifish Immun. 40 (2014) 634-643.

[19] A. Sfacteria, M. Brines, U. Blank, The mast cell plays a central role in the immune system of teleost fish, Mol. Immun. 63 (2015) 3-8.

[20] F.A. Sebastião, L.R. Furlan, D.T. Hashimoto, F. Pilarski, Identification of bacterial fish pathogens in Brazil by Direct Colony PCR and 16S rRNA gene sequencing, Adv. Microbiol. 5 (2015) 409-429.

[21] Clinical and Laboratory Standards Institute, Performance Standards for Antimicrobial Disk Susceptibility Tests, Approved standard M2-A10, Clinical and Laboratory Standards Institute, Wayne, PA, 2009.

[22] R.A. Miller, R.D. Walker, A. Baya, K. Clemens, M. Coles, J.P. Hawke, et al, Antimicrobial susceptibility testing of aquatic bacteria: quality control disk diffusion ranges for Escherichia coli ATCC 25922 and Aeromonas salmonicida subsp. salmonicida ATCC 33658 at 22 and 28 degrees C, J. Clin. Microbiol. 41 (2003) 4318-4323.

[23] I.D. Thilakaratne, G. Rajapaksha, A. Hewakopara, R.P. Rajapakse, A.C. Faizal, Parasitic infections in freshwater ornamental fish in Sri Lanka, Dis. Aquat. Organ. 54 (2003) 157-162.

[24] M. Tavares-Dias, J.R.G. Lemos, M.L. Martins, Parasitic fauna of eight species of ornamental freshwater fish species from the middle Negro river in the Brazilian amazon region, Rev. Bras. Parasit. Vet. 19 (2010) 103-107.

[25] M. Adel, A.A. Saeedi, R. Safari, H.R. Azizi, M. Adel, Pterophyllum scalare
(Perciformes: Cichlidae) a new Paratenic host of Capillaria sp. (Nematoda: Capillariidae) in Iran, World J. Zool. 8 (2013) 371-375.

[26] G. Sharon, M.P. Leibowitz, J.K. Chettri, N. Isakov, D. Zilberg, Comparative study of infection with Tetrahymena of different ornamental fish species, J. Comp. Pathol. 150 (2014) 316-324.

[27] D. Macrì, V.L. Verde, I. Mancuso, S. Reale, A. Passantino, F. Marino, Mycobacteriosis in ornamental fish. Case reports in Sicily and medical-legal considerations, Vet. Res. Commun. 32 (2008) 215-217.

[28] S. Shukla, R. Sharma, S.K. Shukla, Detection and identification of globally distributed mycobacterial fish pathogens in some ornamental fish in India, Folia Microbiol. 58 (2013) 429-436.

[29] M.C. Monroy-Dosta, T. Castro-Barrera, F.J. Fernández-Perrino, L. MayorgaReyes, Inhibition of Aeromonas hydrophila by probiotic strains isolated from the digestive tract of Pterophyllum scalare, Rev. Mex. Ing. Quim 9 (2010) 37-42.

[30] F.C. Guo, P.T. Woo, Experimental infections of Atlantic salmon Salmo salar with Spironucleus barkhanus, Dis. Aquat. Organ. 61 (2004) 59-66.

[31] S. Mankhakhet, N. Suanyuk, C. Tantikitti, W. Phromkunthong, S. Kiriratnikom, T. Lerssutthichawal, et al., Diplomonad flagellates of some ornamental fish cultured in Thailand, Songklanakarin J. Sci. Technol. 34 (2012) 487-494.

[32] N. Sato, N. Yamane, T. Kawamura, Systemic Citrobacter freundii infection among sunfish Mola mola in Matsushima Aquarium, Nippon. Sisan Gakk. 48 (1982) 1551-1557.

[33] L. Aro, K. Correa, A. Martinez, R.Y.J.M. Ildefonso, J.M. Yanez, Characterization of Mycobacterium salmoniphilum as causal agent of mycobacteriosis in Atlantic salmon, Salmo salar L., from a freshwater recirculation system, J. Fish. Dis. 37 (2014) 341-348.

[34] V.V. Nguyen, H.T. Dong, S. Senapin, N. Pirarat, C. Rodkhum, Francisella noatunensis subsp. orientalis, an emerging bacterial pathogen affecting cultured red tilapia (Oreochromis sp.) in Thailand, Aquac. Res. (2015) 1-6.

[35] T.C. Moon, C.D. St Laurent, K.E. Morris, C. Marcet, T. Yoshimura, Y. Sekar, et al., Advances in mast cell biology: new understanding of heterogeneity and function, Mucosal Immun. 3 (2010) 111-128.

[36] M. von Köckritz-Blickwede, O. Goldmann, P. Thulin, K. Heinemann, A. NorrbyTeglund, M. Rohde, et al., Phagocytosis-independent antimicrobial activity of mast cells by means of extracellular trap formation, Blood 111 (2008) 3070-3080.

[37] V. Brinkmann, U. Reichard, C. Goosmann, B. Fauler, Y. Uhlemann, D.S. Weiss, et al., Neutrophil extracellular traps kill bacteria, Science 303 (2004) 1532-1535.

[38] M. von Köckritz-Blickwede, V. Nizet, Innate immunity turned inside-out: antimicrobial defense by phagocyte extracellular traps, J. Mol. Med. 87 (2009) 775-783.

[39] S. Ueki, R.C. Melo, I. Ghiran, L.A. Spencer, A.M. Dvorak, P.F. Weller, Eosinophil extracellular DNA trap cell death mediates lytic release of free secretioncompetent eosinophil granules in humans, Blood 121 (2013) 2074-2083.

[40] S. Wernersson, G. Pejler, Mast cell secretory granules: armed for battle, Nat. Rev. Immun. 14 (2014) 478-494.

[41] N. Musa, L.S. Wei, F. Shaharom, W. Wee, Surveillance of bacteria species in diseased freshwater ornamental fish from aquarium shop, World Appl. Sci. J. 3 (2008) 903-905.

[42] S. Rose, R. Hill, L.E. Bermudez, T. Miller-Morgan, Imported ornamental fish are colonized with antibiotic-resistant bacteria, J. Fish. Dis. 36 (2013) 533-542.

[43] S.M. Awad, Studies on Prevailing Bacterial Diseases in Carp, Ph.D., Fish Diseases and Management Dept., Fac. of Veterinary Medicine, Suez Canal University, 2011.

[44] S.B. Pádua, D.P. Marques, F.A. Sebastião, F. Pilarski, M.L. Martins, M.M. Ishikawa, Isolation, characterization and pathology of Citrobacter freundii infection in native Brazilian catfish Pseudoplatystoma, Braz. J. Vet. Pathol. 7 (2014) 151-157.

[45] S. Sangmaneedet, S.A. Smith, Efficacy of various chemotherapeutic agents on the growth of Spironucleus vortens, an intestinal parasite of the freshwater angelfish, Dis. Aquat. Organ. 38 (1999) 47-52.

[46] C.O. Millet, D. Lloyd, C. Williams, D. Williams, G. Evans, R.A. Saunders, et al., Effect of garlic and allium-derived products on the growth and metabolism of Spironucleus vortens, Exp. Parasitol. 127 (2011) 490-499.

[47] C.F. Williams, D. Lloyd, D. Kolarich, K. Alagesan, M. Duchêne, J. Cable, et al., Disrupted intracellular redox balance of the diplomonad fish parasite Spironucleus vortens by 5-nitroimidazoles and garlic-derived compounds, Vet. Parasitol. 190 (2012) 62-73.

[48] S.T. Perlberg, A. Diamant, R. Ofir, D. Zilberg, Chracterization of swim bladder noninflation (SBN) in angelfish, Pterophyllum scalare (Schultz), and the effect of exposure to methylene blue, J. Fish. Dis. 31 (2008) 215-228.

[49] C. Sanabria, A. Diamant, D. Zilberg, Effects of commonly used disinfectants and temperature on swim bladder non-inflation in freshwater angelfish, Pterophyllum scalare (Lichtenstein), Aquaculture 292 (2009) 158-165. 